\title{
PENGEMBANGAN PERANGKAT PEMBELAJARAN BERBASIS PRAKTIKUM INKUIRI TERBIMBING UNTUK MEWUJUDKAN HASIL BELAJAR BERKARAKTER
}

\author{
Joko Budi Poernomo
}

\begin{abstract}
Abstrak
Pada masa kini ini kita semua terkesima dengan perkembangan kehidupan berbangsa dan bernegara Indonesia. Pada tataran kehidupan masyarakat banyak gejala perubahan perilaku dan tatanan dalam masyarakat. Makin banyak perilaku masyarakat yang menunjukkan pola hidup yang sarat dengan ketidakpedulian, keputusasaan, mudah menyerah, etos kerja rendah, konflik atau perselisihan antar warga bahkan antar pelajar. Pada tataran kehidupan bernegara, makin banyak kita amati gejala penyalahgunaan kewenangan/kekuasaan, kecurangan, kebohongan, ketidakadilan, ketidakpercayaan, dan ketidakpedulian. Ini semua menunjukkan makin lunturnya rasa kebangsaan dan makin tebalnya egoisme pribadi, kelompok, dan/atau suku. Yang lebih meresahkan lagi adalah gejala bahwa generasi muda sudah makin jauh dari ajaran agama dan akar budaya leluhurnya, mungkin karena pengaruh suguhan budaya asing lewat berbagai media
\end{abstract}


informasi dan komunikasi, baik cetak maupun elektronik. Semua ini telah menyentak kesadaran pendidik dan tokoh masyarakat yang peduli pada nasib bangsa, bahkan juga para petinggi Negara. Oleh sebab itu, untuk lima tahun ke depan pendidikan karakter, budaya, dan kewirausahaan diberi perhatian besar oleh pengambil kebijakan pendidikan di Pusat dan daerah tentu saja diharapkan dapat menjabarkan kebijakan ini ke dalam program pendidikan nyata sampai tingkat dasar sampai perguruan tinggi. Tatanan pembelajaran karakter tentunya diawali dari perangkat pembelajaran yang mampu mengangkat karakter siswa dan mahasiswa. Adapun prsayarat yang bersesuaian dengan pembelajaran yang dapat mewakili nilai-nilai karakter agar tertampilkan dalam setiap pembelajaran. Tulisan ini akan memberikan informasi tentang beberapa persiapan pembelajaran yang digunakan dalam menata kembali agar peserta didik mengaplikasikan nilai-nilai karakter yang terilhami dalam pembelajaran.

Kata kunci: Perangkat pembelajaran IPA, nilai-nilai karakter 


\section{A. Pendahuluan}

Kurikulum Tingkat Satuan Pendidikan merupakan kurikulum berbasis kompetensi karena lebih menekankan pada kompetensi-kompetensi yang harus dikuasai oleh siswa. Kompetensi-kompetensi yang harus dikuasai siswa tersebut dijabarkan mulai dari silabus yang kemudian terdapat indikator pencapaian kompetensi. Pada kurikulum sains (IPA) dikembangkan berbagai macam kompetensi dasar yang harus dikuasai siswa. Salah satu kompetensi yang dituntut pada mata pelajaran sains adalah kemampuan melakukan kerja ilmiah.

Berdasarkan panduan Pedoman Khusus Pengembangan Silabus dan Penilaian yang dikeluarkan oleh Depdiknas (2003), kerja ilmiah mempunyai 4 (empat) kompetensi dasar yaitu : merencakan penelitian ilmiah, melaksanakan penelitian ilmiah, mengkomunikasikan hasil penelitian ilmiah dan bersikap ilmiah. Untuk mengembangkan empat macam kompetensi tersebut dapat dilakukan melalui pembelajaran pada siswa dengan kegiatan laboratorium inkuiri.

Pasal 3 Undang-undang nomor 20 tahun 2003 tentang Sistem Pendidikan Nasional menyatakan bahwa: "Pendidikan nasional berfungsi mengembangkan kemampuan dan membentuk watak serta peradaban bangsa yang bermartabat dalam rangka mencerdaskan kehidupan bangsa, bertujuan untuk berkembangnya potensi peserta didik agar menjadi manusia yang beriman dan bertakwa kepada Tuhan Yang Maha Esa, berakhlak mulia, sehat, berilmu, cakap, kreatif, mandiri, dan menjadi warga negara yang demokratis serta bertanggung jawab."Sehubungan dengan hal tersebut, salah satu program utama Kementerian Pendidikan Nasional dalam rangka meningkatkan mutu proses dan output pendidikan pada jenjang pendidikan dasar dan menengah adalah pengembangan pendidikan karakter.

Pengembangan pendidikan karakter adalah suatu peluang bagi penyempurnaan jati diri manusia dengan melalui berbagai macam ketrampilan. Tentunya kondisi pembelajaran berbasis pendidikan karakter harus dipahami sebagai sebuah usaha 
manusia untuk menjadikan dirinya sebagai manusia yang memiliki keutamaan, kesimbangan akdemik dan sisi moral. Pendidikan karakter adalah sesuatu yang mendasar dalam proses pendidikan manusia, bukan pendidikan yang bersifat tambahan atau asesoris belaka, ini berarti setiap proses pendidikan harus didasarkan pendidikan karakter, tidak boleh mengabaikannya.

Tujuan Pendidikan Nasional dalam Undang-Undang Sistem Pendidikan Nasional no 20/2003 Pasal 3, secara jelas menggambarkan kualitas manusia Indonesia yang dicitacitakan. Manusia yang beriman dan bertaqwa kepada Tuhan Yang Maha Esa, berbudi luhur, cakap, sehat, berkepribadian mantap, mandiri, bertanggung jawab dan demokratis. Ungkapan ini jelas menggambarkan kualitas manusia Indonesia yang diharapkan melalui pendidikan. Bahwa menjadikan manusia pintar berpengetahuan berketrampilan hanyalah satu bagian dari usaha besar membentuk manusia seutuhnya, manusia beerkepribadian mantap, manusia yang berkarakter.

Pendidikan bukanlah semata-mata persoalan di ranah kognitif saja, tentunya ranah afektif dan psikomotorik harus mendapatkan peruntukan yang berimbang. Agar tujuan pendidikan nasional dapat tercapai dan seimbang perlu dirancang pendekatan pembelajaran dapat menginternalisasi nilai sehingga menghasilkan peserta didik yang memiliki kemampuan moral dan kemampuan inteletual. Nilai-nilai tersebut dapat direalisasi dalam kegiatan praktikum atau laboratorium yang berpijak pada ketrampilan individu maupun kelompok. Penelitian menunujukkan bahwa siswa yang kualitas karakternya membaik, prestasi akademiknya meningkat. Hal ini mudah dipahami karena penekanan kegiatan praktikum dan pendidikan karakter memilik karakteritik yang sama, seperti : bekerja dengan penuh tanggung jawab, cermat, teratur dan rapi, tepat waktu, jujur, tekun, semangat memberikan yang terbaik, mampu menahan diri dan lain sebagainya tentu pada gilirannya akan berdampak pada peningkatan prestasi akademik.

Tulisan ini hadir untuk membahas tentang realisasi pembelajaran MIPA berpijak pada pendekatan karakter. Fokusnya 
diarahkan untuk mengungkap bagaimana sebenarnya realisasi pembelajaran dengan pijakan pengembangan perangkat pembelajaran agar pendidikan karakter tertampilkan secara nyata dalam pembelajaran dan upaya-upaya perlu dilakukan menuju konstruksi pendidikan MIPA yang menghasilkan prestasi siswa berkarakter.

\section{B. KAJIAN PUSTAKA}

\section{Hakikat IPA}

IPA mempelajari tentang fenomena alam dan berbagai permasalahan dalam kehidupan masyarakat. Fenomena alam dalam IPA dapat ditinjau dari objek, persoalan, tema, dan tempat kejadiannya. Pembelajaran IPA memerlukan kegiatan penyelidikan, baik melalui observasi maupun eksperimen. Selain itu, pembelajaran IPA mengembangkan rasa ingin tahu melalui penemuan berdasarkan pengalaman langsung yang dilakukan melalui kinerja ilmiah. Melalui kinerja ilmiah, peserta didik dilatih untuk memanfaatkan fakta, membangun konsep, prinsip, teori sebagai dasar untuk berpikir kreatif, kritis, analitis, dan divergen. Pembelajaran IPA diharapkan dapat membentuk sikap peserta didik dalam kehidupan sehari-hari sehingga mereka akhirnya menyadari keindahan, keteraturan alam, dan meningkatkan keyakinannya terhadap Tuhan Yang Maha Esa.

\section{Laboratorium Inquiry}

Inkuiri adalah proses pembelajaran yang diawali dengan pengamatan dari pertanyaan-pertanyaan yang muncul. Jawaban atas pertanyaan-pertanyaan tersebut didapat melalui siklus menyusun hipotesis, mengembangkan cara pengujian hipotesis, membuat pengamatan, dan menyusun teori serta konsep yang berdasar pada data dan pengetahuan. 
Langkah-langkah kegiatan inkuiri:

a. Merumuskan masalah (dalam mata pelajaran apapun).

b. Mengamati atau melakukan observasi.

c. Menganalisis dan menyajikan hasil dalam tulisan, gambar, laporan, bagan, tabel, dan karya lain.

d. Mengkomunikasikan atau menyajikan hasil karya pada pembaca, teman sekelas, guru, atau yang lain.

Menurut Wiyanto (2008) dalam kegiatan laboratorium inkuiri, lingkungan belajar dipersiapkan untuk memfasilitasi agar proses pembelajaran berpusat pada siswa dan untuk memberikan bimbingan secukupnya dalam rangka menjamin keberhasilan siswa dalam proses penemuan konsep ilmiah. Bimbingan itu diberikan dalam bentuk pertanyaan dan biasanya diawali dengan pertanyaan yang divergen, yaitu pertanyaan dengan banyak kemungkinan jawaban yang membutuhkan pertimbangan kreatif dan kritis.

Pembelajaran IPA melalui praktikum inkuiri terbimbing, menurut Amien (1987:126), kegiatan inkuiri adalah suatu kegiatan atau pelajaran yang dirancang sedemikian rupa sehingga siswa dapat menemukan konsep-konsep dan prinsip-prinsip melalui proses mentalnya sendiri. Bagi seorang siswa yang membuat penemuan-penemuan ia harus melakukan proses-proses mental, misalnya mengamati, menggolongkan, membuat dugaan, menjelaskan, mengukur, menarik kesimpulan, dan sebagainya.

Menurut jenisnya inkuiri dibagi menjadi dua, yaitu inkuiri bebas dan inkuiri terbimbing. Pada inkuiri siswa bebas melakukan kegiatan tanpa petunjuk khusus dan langkah dari guru. Sehingga pengetahuan awal siswa menjadi sangat penting. Pada inkuiri bebas kemampuan awal dituntut harus tingggi sehingga tidak semua sekolah maupun siswa dapat menggunakan metode ini. Sedangkan pada inkuiri terbimb- 
ing masih memungkinkan guru memberikan arahan yang cukup sehingga siswa tahu apa yang harus dilakukan.

Dalam pembelajaran laboratorium inkuiri, siswa belajar menggunakan ketrampilan berpikir kritis saat mereka berdiskusi dan menganalisis bukti, mengevaluasi ide dan proposisi,merefleksi validitas data, memproses, membuat kesimpulan, kemudian menentukan bagaimana mempresentasikan dan menjelaskan ide-ide atau teori untuk mendapatkan konsep.

Di samping itu, penerapan laboratorium inkuiri terbimbing dengan cara siswa berkelompok dapat meningkatkan partisipasi siswa dalam pembelajaran yang bermakna ddengan membangun hubungan antara konsep dan diskusi konsep yang membantu siswa mengenali gagasan mereka dan membangun pemahaman mereka sebagaimana usaha mereka dalam merekonstruksi konsep dan respon mereka terhadap bimbingan guru ( Bilgin,2009).

\section{Pendidikan berkarakter}

Pengertian karakter menurut Pusat Bahasa Depdiknas adalah "bawaan, hati, jiwa, kepribadian, budi pekerti, personalitas, sifat, tabiat, temperamen, watak". Adapun berkarakter adalah berkepribadian, berperilaku, bersifat, bertabiat dan berwatak. Menurut Tadkiroatun Musfiroh (UNY,2008), karakter mengacu pada serangkaian sikap (attitudes), perilaku (behaviors), motivasi (motivations), dan ketrampilan (skills).

Pendidikan karakter secara terpadu didalam pembelajaran adalah pengenalan nilai-nilai, dan penginternalisasian nilai-nilai ke dalam tingkah laku peserta didik seharihari melalui proses pembelajaran, baik yang berlangsung di dalam maupun di luar kelas pada semua mata pelajaran. 
Pada dasarnya kegiatan pembelajaran, selain untuk menjadikan peserta didik menguasai kompetensi ( materi ) yang ditargetkan, juga dirancang untuk menjadikan peserta didik mengenal, menyadari/peduli, dan menginternalisasikan nilai-nilai dan menjadikannya perilaku

Sejalan dengan rumusan karakteryang dikembangkan pada jenjang SMP dan karakteristik IPA, maka dalam mata pelajaran IPA secara spesifik peserta didik akan dididik dan dilatih untuk mengembangkan karakter pada spesifikasi yang mendiskripsikan tiap nilai pendidikan karakter tersebut adalah seperti yang ditunjukkan dalam tabel berikut ini:

\begin{tabular}{|c|c|}
\hline Nilai/Karakter & Deskripsi \\
\hline Religius & $\begin{array}{c}\text { Sikap mengagumi akan kebesaran } \\
\text { Tuhan }\end{array}$ \\
\hline Kepedulian & $\begin{array}{c}\text { Sikap melindungi dan menjaga ses- } \\
\text { eorang atau sesuatu }\end{array}$ \\
\hline Kejujuran & $\begin{array}{l}\text { Perilaku yang didasarkan pada upa- } \\
\text { menjadikan } \\
\text { dirinya sebagai orang yang selalu } \\
\text { dapat dipercaya } \\
\text { dalam perkataan, tindakan, dan pe- } \\
\text { kerjaan. }\end{array}$ \\
\hline Kecerdasan & $\begin{array}{l}\text { Kemampuan untuk belajar, me- } \\
\text { mahami dan membuat keputusan atau } \\
\text { mempunyai pendapat berdasarkan pe- } \\
\text { nalaran }\end{array}$ \\
\hline Ketangguhan & $\begin{array}{l}\text { Memiliki pendapat atau perasaan } \\
\text { yang kuat dan tidak mungkin berubah }\end{array}$ \\
\hline Demokratis & $\begin{array}{l}\text { Mempercayai kebebasan dan kesa- } \\
\text { maan diantara sesama manusia }\end{array}$ \\
\hline
\end{tabular}




\begin{tabular}{|c|c|}
\hline Rasa ingin tahu & $\begin{array}{l}\text { Sikap dan tindakan yang selalu } \\
\text { berupaya untuk } \\
\text { mengetahui lebih mendalam dan } \\
\text { meluas dari sesuatu } \\
\text { yang dipelajarinya, dilihat, dan } \\
\text { didengar. }\end{array}$ \\
\hline Berpikir logis & $\begin{array}{l}\text { Cara berpikir untuk mendapatkan } \\
\text { alasan yang nalar dan berdasarkan kepu- } \\
\text { tusan yang baik. }\end{array}$ \\
\hline Berpikir kreatif & $\begin{array}{l}\text { Menggunakan atau menghasilkan } \\
\text { ide asli }\end{array}$ \\
\hline Percaya diri & $\begin{array}{l}\text { Sikap yakin akan kemampuan diri } \\
\text { sendiri terhadap pemenuhan tercapainya } \\
\text { setiap keinginan dan harapannya. }\end{array}$ \\
\hline Kedisiplinan & $\begin{array}{l}\text { Tindakan yang menunjukkan } \\
\text { perilaku tertib dan patuh pada berbagai } \\
\text { ketentuan dan peraturan. }\end{array}$ \\
\hline Kemandirian & $\begin{array}{l}\text { Sikap dan perilaku yang tidak mu- } \\
\text { dah tergantung pada orang lain dalam } \\
\text { menyelesaikan tugas-tugas. }\end{array}$ \\
\hline Bertanggung jawab & $\begin{array}{l}\text { Sikap dan perilaku seseorang untuk } \\
\text { melaksanakan tugas dan kewajibannya, } \\
\text { yang seharusnya dia lakukan, terhadap } \\
\text { diri sendiri, masyarakat, lingkungan } \\
\text { (alam, sosial dan budaya), negara dan } \\
\text { Tuhan Yang Maha Esa. }\end{array}$ \\
\hline Peduli lingkungan & $\begin{array}{l}\text { Sikap dan tindakan yang selalu } \\
\text { berupaya mencegah kerusakan pada } \\
\text { lingkungan alam di sekitarnya, dan } \\
\text { mengembangkan upaya-upaya untuk } \\
\text { memperbaiki kerusakan alam yang su- } \\
\text { dah terjadi. }\end{array}$ \\
\hline
\end{tabular}




\begin{tabular}{|c|c|}
\hline Cinta ilmu & $\begin{array}{c}\text { Cara berpikir, bersikap dan berbuat } \\
\text { yang menunjukkan kesetiaan, kepedu- } \\
\text { lian, dan penghargaan yang tinggi terha- } \\
\text { dap pengetahuan. }\end{array}$ \\
\hline $\begin{array}{c}\text { Ketelitian dan } \\
\text { kecermatan }\end{array}$ & $\begin{array}{c}\text { Sikap selalu berhati-hati, bertindak } \\
\text { dengan seksama dan penuh ketelitian }\end{array}$ \\
\hline Santun & $\begin{array}{c}\text { Sifat yang halus dan baik dari } \\
\text { sudut pandang tata bahasa maupun tata } \\
\text { perilakunya ke semua orang. }\end{array}$ \\
\hline Kerjasama & $\begin{array}{l}\text { Sikap yang dilakukan untuk selalu } \\
\text { melibatkan orang lain dalam kelompok } \\
\text { kegiatan untuk mencapai tujuan bersama }\end{array}$ \\
\hline Bergaya hidup & $\begin{array}{l}\text { Segala upaya untuk menerapkan } \\
\text { kebiasaan yang baik dalam menciptakan } \\
\text { hidup yang sehat dan menghindarkan } \\
\text { kebiasaan buruk yang dapat menggang- } \\
\text { gu kesehatan. }\end{array}$ \\
\hline
\end{tabular}

C. Pengembangan Perangkat Pembelajaran MIPA PERANGKAT NILAI SUBSTANSI PENDIDIKAN
KARAKTER

1. Nilai-nilai Dasar yang termuat dalam Standar Kompetensi Lulusan (SKL) Pendidiksan Dasar dan Pendidikan Menengah.

a. Dalam Permendiknas N0.23/2006 tentang Standar kompetensi lulusan secara formal sudah digariskan untuk masing-masing jenis atau satuan pendidikan sejumlah rumusan Standar Kompetensi Lulusan (SKL).Jika diremati secara mendalam, sesungguhnya hampir pada setiap rumusan SKL tersebut implisit atau eksplisit termuat substansi nilai/karakter. Berikut ini dicoba untuk menangkap substansi nilai/ 
karakter yang ada pada setiap SKL tersebut.

b. Substansi Nilai/Karakter yang ada pada SKL SD/MI/ SDLB $^{*} /$ Paket A

\begin{tabular}{|c|l|l|}
\hline No. & \multicolumn{1}{|c|}{ Rumusan SKL } & Nilai/Karakter \\
\hline 1 & $\begin{array}{l}\text { Menjalankan ajaran agama yang di- } \\
\text { anut sesuai dengan tahap perkem- } \\
\text { bangan anak }\end{array}$ & Iman dan taqwa \\
\hline 2 & $\begin{array}{l}\text { Mengenal kekurangan dan kelebi- } \\
\text { han diri sendiri }\end{array}$ & jujur \\
\hline 3 & $\begin{array}{l}\text { Mematuhi aturan-aturan sosial yang } \\
\text { berlaku dalam lingkungannya }\end{array}$ & disiplin \\
\hline 4 & $\begin{array}{l}\text { Menghargai keberagaman agama, } \\
\text { budaya, suku, ras, dan golongan } \\
\text { sosial ekonomi di lingkungan seki- } \\
\text { tarnya }\end{array}$ & $\begin{array}{l}\text { Terbuka, nasion- } \\
\text { alistik }\end{array}$ \\
\hline 5 & $\begin{array}{l}\text { Menggunakan informasi tentang } \\
\text { lingkungan sekitar secara logis, kri- } \\
\text { tis, dan kreatif }\end{array}$ & Bernalar, kreatif \\
\hline 6 & $\begin{array}{l}\text { Menunjukkan kemampuan berpikir } \\
\text { logis, kritis, dan kreatif, dengan } \\
\text { bimbingan guru/pendidik }\end{array}$ & Bernalar, kreatif \\
\hline 7 & $\begin{array}{l}\text { Menunjukkan rasa keingintahuan } \\
\text { yang tinggi dan menyadari poten- } \\
\text { sinya }\end{array}$ & Terbuka, bernalar \\
\hline 8 & $\begin{array}{l}\text { Menunjukkan kemampuan mem- } \\
\text { ecahkan masalah sederhana dalam } \\
\text { kehidupan sehari-hari }\end{array}$ & bernalar \\
\hline 9 & $\begin{array}{l}\text { Menunjukkan kemampuan menge- } \\
\text { nali gejala alam dan sosial di ling- } \\
\text { kungan sekitar }\end{array}$ & Terbuka, bernalar \\
\hline 10 & $\begin{array}{l}\text { Menunjukkan kecintaan dan } \\
\text { kepedulian terhadap lingkungan }\end{array}$ & $\begin{array}{l}\text { Peduli, tanggung } \\
\text { jawab }\end{array}$ \\
\hline 11 & $\begin{array}{l}\text { Menunjukkan kecintaan dan ke- } \\
\text { banggaan terhadap bangsa, negara, } \\
\text { dan tanah air Indonesia }\end{array}$ & nasionalistik \\
\hline
\end{tabular}




\begin{tabular}{|c|l|l|}
\hline 12 & $\begin{array}{l}\text { Menunjukkan kemampuan untuk } \\
\text { melakukan kegiatan seni dan bu- } \\
\text { daya lokal }\end{array}$ & $\begin{array}{l}\text { Kreatif, tanggung } \\
\text { jawab }\end{array}$ \\
\hline 13 & $\begin{array}{l}\text { Menunjukkan kebiasaan hidup ber- } \\
\text { sih, sehat, bugar, aman, dan me- } \\
\text { manfaatkan waktu luang }\end{array}$ & $\begin{array}{l}\text { Bersih, tanggung } \\
\text { jawab }\end{array}$ \\
\hline 14 & $\begin{array}{l}\text { Berkomunikasi secara jelas dan san- } \\
\text { tun }\end{array}$ & Santun \\
\hline 15 & $\begin{array}{l}\text { Bekerja sama dalam kelompok, to- } \\
\text { long-menolong, dan menjaga diri } \\
\text { sendiri dalam lingkungan keluarga } \\
\text { dan teman sebaya }\end{array}$ & $\begin{array}{l}\text { Gotong royong, } \\
\text { peduli }\end{array}$ \\
\hline 16 & $\begin{array}{l}\text { Menunjukkan kegemaran membaca } \\
\text { dan menulis }\end{array}$ & gigih \\
\hline 17 & $\begin{array}{l}\text { Menunjukkan keterampilan menyi- } \\
\text { mak, berbicara, membaca, menulis, } \\
\text { dan berhitung }\end{array}$ & bernalar \\
\hline
\end{tabular}

2. Substansi Nilai/Karakter yang ada pada SKL SMP/ MTs/SMPLB/Paket B

\begin{tabular}{|c|l|l|}
\hline No. & \multicolumn{1}{|c|}{ Rumusan SKL } & $\begin{array}{c}\text { Nilai/Kara- } \\
\text { kter }\end{array}$ \\
\hline 1 & $\begin{array}{l}\text { Mengamalkan ajaran agama yang dia- } \\
\text { nut sesuai dengan tahap perkembangan } \\
\text { remaja }\end{array}$ & $\begin{array}{l}\text { Iman dan } \\
\text { taqwa }\end{array}$ \\
\hline 2 & Menunjukkan sikap percaya diri & adil \\
\hline 3 & $\begin{array}{l}\text { Mematuhi aturan-aturan sosial yang ber- } \\
\text { laku dalam lingkungan yang lebih luas }\end{array}$ & disiplin \\
\hline 4 & $\begin{array}{l}\text { Menghargai keberagaman agama, buda- } \\
\text { ya, suku, ras, dan golongan sosial eko- } \\
\text { nomi dalam lingkup nasional }\end{array}$ & nasionalistik \\
\hline 5 & $\begin{array}{l}\text { Mencari dan menerapkan informasi dari } \\
\text { lingkungan sekitar dan sumber-sumber } \\
\text { lain secara logis, kritis, dan kreatif }\end{array}$ & $\begin{array}{l}\text { Bernalar, kre- } \\
\text { atif }\end{array}$ \\
\hline 6 & $\begin{array}{l}\text { Menunjukkan kemampuan berpikir lo- } \\
\text { gis, kritis, kreatif, dan inovatif }\end{array}$ & $\begin{array}{l}\text { bernalar, kre- } \\
\text { atif }\end{array}$ \\
\hline
\end{tabular}

148 Jurnal PHENOMENON, Volume 1 Nomor 1, Juli 2011 


\begin{tabular}{|c|c|c|}
\hline 7 & $\begin{array}{l}\text { Menunjukkan kemampuan belajar se- } \\
\text { cara mandiri sesuai dengan potensi yang } \\
\text { dimilikinya }\end{array}$ & $\begin{array}{l}\text { Gigih, tang- } \\
\text { gung jawab }\end{array}$ \\
\hline 8 & $\begin{array}{l}\text { Menunjukkan kemampuan menganali- } \\
\text { sis dan memecahkan masalah dalam ke- } \\
\text { hidupan sehari-hari }\end{array}$ & bernalar \\
\hline 9 & Mendeskripsi gejala alam dan sosial & $\begin{array}{l}\text { Terbuka, ber- } \\
\text { nalar }\end{array}$ \\
\hline 10 & $\begin{array}{l}\text { Memanfaatkan lingkungan secara ber- } \\
\text { tanggung jawab }\end{array}$ & $\begin{array}{l}\text { T a nggung } \\
\text { jawab }\end{array}$ \\
\hline 11 & $\begin{array}{l}\text { Menerapkan nilai-nilai kebersamaan } \\
\text { dalam kehidupan bermasyarakat, ber- } \\
\text { bangsa, dan bernegara demi terwujud- } \\
\text { nya persatuan dalam Negara Kesatuan } \\
\text { Republik Indonesia }\end{array}$ & $\begin{array}{l}\text { Nasionalis- } \\
\text { tik, gotong } \\
\text { royong }\end{array}$ \\
\hline 12 & karya seni dan budaya na- & $\begin{array}{l}\text { Peduli, nasi- } \\
\text { onalistik }\end{array}$ \\
\hline 13 & n memi- & $\begin{array}{l}\text { Ta ng g u ng } \\
\text { jawab, kreatif }\end{array}$ \\
\hline 14 & $\begin{array}{l}\mathrm{t} \text {, bugar, } \\
\text { ג luang }\end{array}$ & \begin{tabular}{|l}
$\begin{array}{l}\text { Bersih dan } \\
\text { sehat }\end{array}$ \\
\end{tabular} \\
\hline 15 & teraksi secara & $\begin{array}{l}\text { Santun, ber- } \\
\text { nalar }\end{array}$ \\
\hline 16 & $\begin{array}{l}\text { Memahami hak dan kewajiban diri dan } \\
\text { orang lain dalam pergaulan di masyara- } \\
\text { kat }\end{array}$ & $\begin{array}{l}\text { Terbuka, } \\
\text { Tanggung } \\
\text { jawab }\end{array}$ \\
\hline 17 & Menghargai adanya perbedaan pendapat & Terbuka, adil \\
\hline 18 & $\begin{array}{l}\text { Menunjukkan kegemaran membaca dan } \\
\text { menulis naskah pendek sederhana }\end{array}$ & Gigih, kreatif \\
\hline 19 & $\begin{array}{l}\text { Menunjukkan keterampilan menyimak, } \\
\text { berbicara, membaca, dan menulis dalam } \\
\text { bahasa Indonesia dan bahasa Inggris } \\
\text { sederhana }\end{array}$ & Gigih, kreatif \\
\hline 20 & $\begin{array}{l}\text { Menguasai pengetahuan yang diper- } \\
\text { lukan untuk mengikuti pendidikan } \\
\text { menengah }\end{array}$ & $\begin{array}{l}\text { Bervisi, } \\
\text { nalar }\end{array}$ \\
\hline
\end{tabular}


3. Substansi Nilai/Karakter yang ada pada SKLSMA/MA/ SMALB* $^{*}$ Paket C

\begin{tabular}{|c|l|l|}
\hline No. & \multicolumn{1}{|c|}{ Rumusan SKL } & \multicolumn{1}{|c|}{$\begin{array}{c}\text { Nilai/Kara- } \\
\text { kter }\end{array}$} \\
\hline 1 & $\begin{array}{l}\text { Berperilaku sesuai dengan ajaran agama } \\
\text { yang dianut sesuai dengan perkemban- } \\
\text { gan remaja }\end{array}$ & $\begin{array}{l}\text { Iman dan } \\
\text { taqwa }\end{array}$ \\
\hline 2 & $\begin{array}{l}\text { Mengembangkan diri secara optimal } \\
\text { dengan memanfaatkan kelebihan diri } \\
\text { serta memperbaiki kekurangannya }\end{array}$ & adil \\
\hline 3 & $\begin{array}{l}\text { Menunjukkan sikap percaya diri dan } \\
\text { bertanggung jawab atas perilaku, per- } \\
\text { buatan, dan pekerjaannya }\end{array}$ & $\begin{array}{l}\text { Tanggung } \\
\text { jawab }\end{array}$ \\
\hline 4 & $\begin{array}{l}\text { Berpartisipasi dalam penegakan aturan- } \\
\text { aturan sosial }\end{array}$ & disiplin \\
\hline 5 & $\begin{array}{l}\text { Menghargai keberagaman agama, bang- } \\
\text { sa, suku, ras, dan golongan sosial eko- } \\
\text { nomi dalam lingkup global }\end{array}$ & nasionalistik \\
\hline 6 & $\begin{array}{l}\text { Membangun dan menerapkan informasi } \\
\text { dan pengetahuan secara logis, kritis, kre- } \\
\text { atif, dan inovatif }\end{array}$ & bernalar \\
\hline 7 & $\begin{array}{l}\text { Menunjukkan kemampuan berpikir lo- } \\
\text { gis, kritis, kreatif, dan inovatif dalam } \\
\text { pengambilan keputusan }\end{array}$ & bernalar \\
\hline 8 & $\begin{array}{l}\text { Menunjukkan kemampuan mengem- } \\
\text { bangkan budaya belajar untuk pember- } \\
\text { dayaan diri }\end{array}$ & bervisi \\
\hline 9 & $\begin{array}{l}\text { Menunjukkan sikap kompetitif dan } \\
\text { sportif untuk mendapatkan hasil yang } \\
\text { terbaik }\end{array}$ & gigih \\
\hline 10 & $\begin{array}{l}\text { Menunjukkan kemampuan menganali- } \\
\text { sis dan memecahkan masalah kompleks }\end{array}$ & bernalar \\
\hline 11 & $\begin{array}{l}\text { Menunjukkan kemampuan menganali- } \\
\text { sis gejala alam dan sosial }\end{array}$ & bernalar \\
\hline 12 & $\begin{array}{l}\text { Memanfaatkan lingkungan secara } \\
\text { produktif dan bertanggung jawab }\end{array}$ & $\begin{array}{l}\text { Tanggung } \\
\text { jawab }\end{array}$ \\
\hline
\end{tabular}




\begin{tabular}{|c|l|l|}
\hline 13 & $\begin{array}{l}\text { Berpartisipasi dalam kehidupan berma- } \\
\text { syarakat, berbangsa, dan bernegara se- } \\
\text { cara demokratis dalam wadah Negara } \\
\text { Kesatuan Republik Indonesia }\end{array}$ & nasionalistik \\
\hline 14 & $\begin{array}{l}\text { Mengekspresikan diri melalui kegiatan } \\
\text { seni dan budaya }\end{array}$ & peduli \\
\hline 15 & Mengapresiasi karya seni dan budaya & kreatif \\
\hline 16 & $\begin{array}{l}\text { Menghasilkan karya kreatif, baik indi- } \\
\text { vidual maupun kelompok }\end{array}$ & Kreatif \\
\hline 17 & $\begin{array}{l}\text { Menjaga kesehatan dan keamanan diri, } \\
\text { kebugaran jasmani, serta kebersihan } \\
\text { lingkungan }\end{array}$ & bersih \\
\hline 18 & $\begin{array}{l}\text { Berkomunikasi lisan dan tulisan secara } \\
\text { efektif dan santun }\end{array}$ & Santun \\
\hline 19 & $\begin{array}{l}\text { Memahami hak dan kewajiban diri dan } \\
\text { orang lain dalam pergaulan di masyara- } \\
\text { kat }\end{array}$ & Tanggung \\
jawab
\end{tabular}

4. Substansi Nilai/Karakter yang ada pada SKL MK/MAK

\begin{tabular}{|c|l|l|}
\hline No. & \multicolumn{1}{|c|}{ Rumusan SKL } & Nilai/Karakter \\
\hline 1 & $\begin{array}{l}\text { Berperilaku sesuai dengan ajaran } \\
\text { agama yang dianut sesuai dengan } \\
\text { perkembangan remaja }\end{array}$ & $\begin{array}{l}\text { Iman } \\
\text { taqwa }\end{array}$ \\
\hline 2 & $\begin{array}{l}\text { Mengembangkan diri secara optimal } \\
\text { dengan memanfaatkan kelebihan diri } \\
\text { serta memperbaiki kekurangannya }\end{array}$ & Gigih, adil \\
\hline 3 & $\begin{array}{l}\text { Menunjukkan sikap percaya diri dan } \\
\text { bertanggung jawab atas perilaku, per- } \\
\text { buatan, dan pekerjaannya }\end{array}$ & $\begin{array}{l}\text { Tanggung jaw- } \\
\text { ab }\end{array}$ \\
\hline 4 & $\begin{array}{l}\text { Berpartisipasi dalam penegakan } \\
\text { aturan-aturan sosial }\end{array}$ & disiplin \\
\hline 5 & $\begin{array}{l}\text { Menghargai keberagaman agama, } \\
\text { bangsa, suku, ras, dan golongan sosial } \\
\text { ekonomi dalam lingkup global }\end{array}$ & nasionalistik \\
\hline
\end{tabular}




\begin{tabular}{|c|l|l|}
\hline 6 & $\begin{array}{l}\text { Membangun dan menerapkan infor- } \\
\text { masi dan pengetahuan secara logis, } \\
\text { kritis, kreatif, dan inovatif }\end{array}$ & kreatif \\
\hline 7 & $\begin{array}{l}\text { Menunjukkan kemampuan berpikir } \\
\text { logis, kritis, kreatif, dan inovatif dalam } \\
\text { pengambilan keputusan }\end{array}$ & $\begin{array}{l}\text { Bernalar, kre- } \\
\text { atif }\end{array}$ \\
\hline 8 & $\begin{array}{l}\text { Menunjukkan kemampuan mengem- } \\
\text { bangkan budaya belajar untuk pem- } \\
\text { berdayaan diri }\end{array}$ & $\begin{array}{l}\text { Peduli ,tang- } \\
\text { gung jawab }\end{array}$ \\
\hline 9 & $\begin{array}{l}\text { Menunjukkan sikap kompetitif dan } \\
\text { sportif untuk mendapatkan hasil yang } \\
\text { terbaik }\end{array}$ & Gigih, adil \\
\hline 10 & $\begin{array}{l}\text { Menunjukkan kemampuan menganal- } \\
\text { isis dan memecahkan masalah kom- } \\
\text { pleks }\end{array}$ & bernalar \\
\hline 11 & $\begin{array}{l}\text { Menunjukkan kemampuan menganal- } \\
\text { isis gejala alam dan sosial }\end{array}$ & bernalar \\
\hline 12 & $\begin{array}{l}\text { Memanfaatkan lingkungan secara } \\
\text { produktif dan bertanggung jawab }\end{array}$ & $\begin{array}{l}\text { Peduli, tang- } \\
\text { gung jawab }\end{array}$ \\
\hline 13 & $\begin{array}{l}\text { Berpartisipasi dalam kehidupan ber- } \\
\text { masyarakat, berbangsa, dan bernegara } \\
\text { secara demokratis dalam wadah Nega- } \\
\text { ra Kesatuan Republik Indonesia }\end{array}$ & nasionalistik \\
\hline 14 & $\begin{array}{l}\text { Mengekspresikan diri melalui keg- } \\
\text { iatan seni dan budaya }\end{array}$ & Peduli, kreatif \\
\hline 15 & Mengapresiasi karya seni dan budaya & kreatif \\
\hline 16 & $\begin{array}{l}\text { Menghasilkan karya kreatif, baik indi- } \\
\text { vidual maupun kelompok }\end{array}$ & kreatif \\
\hline 17 & $\begin{array}{l}\text { Menjaga kesehatan dan keamanan } \\
\text { diri, kebugaran jasmani, serta kebersi- } \\
\text { han lingkungan }\end{array}$ & Bersih, peduli \\
\hline 18 & $\begin{array}{l}\text { Berkomunikasi lisan dan tulisan secara } \\
\text { efektif dan santun }\end{array}$ & Santun \\
\hline 19 & $\begin{array}{l}\text { Memahami hak dan kewajiban diri } \\
\text { san orang lain dalam pergaulan di ma- } \\
\text { syarakat }\end{array}$ & Terbuka, adil \\
\hline
\end{tabular}




\begin{tabular}{|c|l|l|}
\hline 20 & $\begin{array}{l}\text { Menghargai adanya perbedaan } \\
\text { pendapat dan berempati terhadap } \\
\text { orang lain }\end{array}$ & Terbuka, adil \\
\hline 21 & $\begin{array}{l}\text { Menunjukkan keterampilan membaca } \\
\text { dan menulis naskah secara sistematis } \\
\text { dan estetis }\end{array}$ & Gigih,terbuka \\
\hline 22 & $\begin{array}{l}\text { Menunjukkan keterampilan menyi- } \\
\text { mak, membaca, menulis, dan berbicara } \\
\text { dalam bahasa Indonesia dan Inggris }\end{array}$ & Gigih, bernalar \\
\hline 23 & $\begin{array}{l}\text { Menguasai kompetensi program ke- } \\
\text { ahlian dan kewirausahaan baik un- } \\
\text { tuk memenuhi tuntutan dunia kerja } \\
\text { maupun untuk mengikuti pendidikan } \\
\text { tinggi sesuai dengan kejuruannya }\end{array}$ & $\begin{array}{l}\text { Bervisi, gigih, } \\
\text { anggung jaw- } \\
\text { ab }\end{array}$ \\
\hline
\end{tabular}

5. Konfigurasi Nilai/karakter untuk semua Satuan Pendidikan

Secara psikologis dan sosial kultural pembentukan karakter dalam diri individu merupakan fungsi dari seluruh potensi individu manusia (kognitif, afektif, konatif, dan psikomotorik) dalam konteks interaksi sosial kultural (dalam keluarga, sekolah, dan masyarakat) dan berlangsung sepanjang hayat. Konfigurasi karakter dalam konteks totalitas proses psikologis dan sosialkultural tersebut dapat dikelompokan dalam: Olah Hati (Spiritual and emotional development), Olah Pikir (intellectual development), Olah Raga dan Kinestetik (Physical and kinestetic development), dan Olah Rasa dan Karsa (Affective and Creativity development) yang secara diagramatik dapat digambarkan sebagai berikut.

6. Pengembangan nilai-nilai dan karakater diintegrasikan dalam setiap pokok bahasan dari setiap mata pelajaran. Nilai-nilai tersebut dicantumkan dalam Silabus dan Rencana Program Pembelajaran (RPP). Pengembangan nilainilai tersebut dalam Silabus ditempuh melalui cara-cara 
sebaghai berikut

a. mengkaji Standar Kompetensi (SK) dan Kompetensi Dasar (KD) untuk menentukan apakah kandungan nilai-nilai dan karakter yang secara tersirat atau tersurat dalam SK dan KD di atas sudah tercakup di dalamnya

b. menggunakan tabel 1 yang memperlihatkan keterkaitan antara SK/KD dengan nilai dan indikator untuk menentukan nilai yang akan dikembangkan

c. mencantumkankan nilai-nilai dan karakter bangsa dalam tabel 1 tersebut ke dalam silabus

d. mencantumkan nilai-nilai yang sudah tercantum dalam silabus ke RPP

e. mengembangkan proses pembelajaran peserta didik aktif yang memungkinkan peserta didik memiliki kesempatan melakukan internalisasi nilai dan menunjukkannya dalam perilaku yang sesuai

f. memberikan bantuan kepada peserta didik yang mengalami kesulitan untuk internalisasi nilai mau pun untuk menunjukkannya dalam perilaku.

Gambaran tentang sampel silabus dan rencana pembelajaran tergambarkan pada paparan berikut :

\section{RENCANA PELAKSANAAN PEMBELAJARAN}

(RPP)

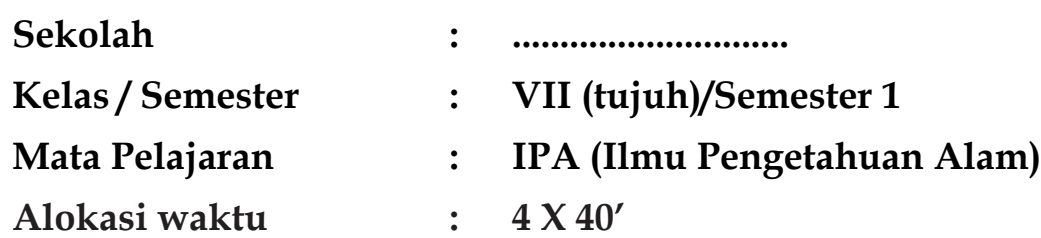

Standar Kompetensi : $\quad 1$ Memahami prosedur ilmiah untuk mempelajari benda- 
benda alam dengan menggunakan peralatan.

Kompetensi Dasar

: 1.2 Mendeskripsikan pengertian suhu dan pengukurannya.

Tujuan Pembelajaran : Peserta didik dapat:

1. Menjelaskan pengertian suhu.

2. Menjelaskan bagian-bagian dari termometer.

3. Menyebutkan jenis-jenis termometer.

4. Menggunakan termometer untuk mengukur suhu suatu benda.

5. Membaca skala pada termometer.

6. Membandingkan skala pada termometer Celsius dengan termometer skala Kelvin, Reamur, dan Fahrenheit.

Karakter siswa yang diharapkan :

Disiplin (Discipline)

Rasa hormat dan perhatian (respect)

Tekun (diligence)

Tanggung jawab ( responsibility )

Ketelitian (carefulness)

Materi Pembelajaran : Suhu

Metode Pembelajaran : Model: 
Joko Budi Poernomo

-Direct Instruction (DI)

-Cooperative Learning

Metode:

-Diskusi kelompok

-Eksperimen

\section{Langkah-langkah Kegiatan}

\section{PERTEMUAN PERTAMA}

\section{a. Kegiatan Pendahuluan}

- Motivasi dan apersepsi

- Apakah hubungan suhu dengan panas atau dingin?

- Alat apakah yang dipakai untuk mengukur bila suhu tubuhmu terasa panas?

- Prasyarat pengetahuan

- Apakah yang dimaksud dengan suhu?

- Apakah Satuan Internasional dari besaran suhu?

- Pra eksperimen

- Berhati-hatilah menggunakan peralatan yang terbuat dari kaca.

\section{b. Kegiatan Inti}

- Eksplorasi

Dalam kegiatan eksplorasi, guru:

* Menjelaskan pengertian suhu.

Menjelaskan bagian-bagian dari termometer

melibatkan peserta didik mencari informasi yang luas dan dalam tentang topik/tema materi yang akan dipelajari dengan menerapkan prinsip alam takambang jadi guru dan belajar dari aneka sumber;

menggunakan beragam pendekatan pembelajaran, 
media pembelajaran, dan sumber belajar lain;

$\rightarrow$ memfasilitasi terjadinya interaksi antarpeserta didik serta antara peserta didik dengan guru, lingkungan, dan sumber belajar lainnya;

melibatkan peserta didik secara aktif dalam setiap kegiatan pembelajaran; dan

memfasilitasi peserta didik melakukan percobaan di laboratorium, studio, atau lapangan.

\section{- Elaborasi}

Dalam kegiatan elaborasi, guru:

membiasakan peserta didik membaca dan menulis yang beragam melalui tugas-tugas tertentu yang bermakna;

memfasilitasi peserta didik melalui pemberian tugas, diskusi, dan lain-lain untuk memunculkan gagasan baru baik secara lisan maupun tertulis;

Guru membimbing peserta didik dalam pembentukan kelompok.

Secara kelompok, peserta didik mendiskusikan pengertian besaran dan klasifikasinya, kemudian membuat kesimpulan sementara dan anggota masing-masing kelompok meng-komunikasikannya.

memberi kesempatan untuk berpikir, menganalisis, menyelesaikan masalah, dan bertindak tanpa rasa takut;

memfasilitasi peserta didik dalam pembelajaran kooperatif dan kolaboratif;

$*$ memfasilitasi peserta didik berkompetisi secara sehat untuk meningkatkan prestasi belajar;

memfasilitasi peserta didik membuat laporan eksplorasi yang dilakukan baik lisan maupun ter- 
tulis, secara individual maupun kelompok;

$\rightarrow$ memfasilitasi peserta didik untuk menyajikan hasil kerja individual maupun kelompok;

memfasilitasi peserta didik melakukan pameran, turnamen, festival, serta produk yang dihasilkan;

memfasilitasi peserta didik melakukan kegiatan yang menumbuhkan kebanggaan dan rasa percaya diri peserta didik.

\section{- Konfirmasi}

Dalam kegiatan konfirmasi, guru:

memberikan umpan balik positif dan penguatan dalam bentuk lisan, tulisan, isyarat, maupun hadiah terhadap keberhasilan peserta didik,

memberikan konfirmasi terhadap hasil eksplorasi dan elaborasi peserta didik melalui berbagai sumber,

memfasilitasi peserta didik melakukan refleksi untuk memperoleh pengalaman belajar yang telah dilakukan,

- memfasilitasi peserta didik untuk memperoleh pengalaman yang bermakna dalam mencapai kompetensi dasar:

$>$ berfungsi sebagai narasumber dan fasilitator dalam menjawab pertanyaan peserta didik yang menghadapi kesulitan, dengan menggunakan bahasa yang baku dan benar;

$>$ membantu menyelesaikan masalah;

$>$ memberi acuan agar peserta didik dapat melakukan pengecekan hasil eksplorasi;

$>$ memberi informasi untuk bereksplorasi lebih jauh; 
> memberikan motivasi kepada peserta didik yang kurang atau belum berpartisipasi aktif.

\section{c. Kegiatan Penutup}

Dalam kegiatan penutup, guru:

$\leftrightarrow$ bersama-sama dengan peserta didik dan/atau sendiri membuat rangkuman/simpulan pelajaran;

melakukan penilaian dan/atau refleksi terhadap kegiatan yang sudah dilaksanakan secara konsisten dan terprogram;

memberikan umpan balik terhadap proses dan hasil pembelajaran;

merencanakan kegiatan tindak lanjut dalam bentuk pembelajaran remedi, program pengayaan, layanan konseling dan/atau memberikan tugas baik tugas individual maupun kelompok sesuai dengan hasil belajar peserta didik;

\section{PERTEMUAN KEDUA}

\section{a Kegiatan Pendahuluan}

- Motivasi dan apersepsi

- Hasil pengukuran suhu harus dinyatakan dengan satuan; satuan apakah yang digunakan?

- Apakah satuan suhu dalam Standar Internasional (SI)?

. Prasyarat pengetahuan

- Guru menunjukkan sebuah termometer, peserta didik diminta untuk membaca skala.

\section{b. Kegiatan Inti}

\section{- Eksplorasi}

Dalam kegiatan eksplorasi, guru: 
$\$$ Menggunakan termometer untuk mengukur suhu suatu benda.

\% Membaca skala pada termometer.

* Membandingkan skala pada termometer Celsius dengan termometer skala Kelvin, Reamur, dan Fahrenheit.

melibatkan peserta didik mencari informasi yang luas dan dalam tentang topik/tema materi yang akan dipelajari dengan menerapkan prinsip alam takambang jadi guru dan belajar dari aneka sumber;

menggunakan beragam pendekatan pembelajaran, media pembelajaran, dan sumber belajar lain;

$\leftrightarrow$ memfasilitasi terjadinya interaksi antarpeserta didik serta antara peserta didik dengan guru, lingkungan, dan sumber belajar lainnya;

melibatkan peserta didik secara aktif dalam setiap kegiatan pembelajaran; dan

$\checkmark$ memfasilitasi peserta didik melakukan percobaan di laboratorium, studio, atau lapangan.

\section{- Elaborasi}

Dalam kegiatan elaborasi, guru:

* Melalui diskusi kelas, guru menginformasikan cara membaca skala termometer yang benar.

G Guru mendemonstrasikan langkah-langkah penggunaan, pengukuran suhu suatu objek, dan pembacaan skala pada termometer.

Melalui diskusi kelompok, peserta didik diberi tugas membandingkan skala pada termometer Celsius dengan termometer Kelvin, Reamur, dan Fahrenheit.

Guru memberikan informasi cara menentukan 
skala termometer Celsius dengan termometer Kelvin, Reamur, dan Fahrenheit dengan perbandingan Tc: Tk :Tr $:($ Tf - 32) $=5:(\mathrm{Tc}+273): 4: 9$.

Guru memberikan contoh soal latihan mengenai cara menghitung skala termometer Celsius, Kelvin, Reamur, dan Fahrenheit.

- Konfirmasi

Dalam kegiatan konfirmasi, guru:

Guru bertanya jawab tentang hal-hal yang belum diktahui siswa

- Guru bersama siswa bertanya jawab meluruskan kesalahan pemahaman, memberikan penguatan dan penyimpulan

\section{c. Kegiatan Penutup}

Dalam kegiatan penutup, guru:

$\checkmark$ bersama-sama dengan peserta didik dan/atau sendiri membuat rangkuman/simpulan pelajaran;

melakukan penilaian dan/atau refleksi terhadap kegiatan yang sudah dilaksanakan secara konsisten dan terprogram;

memberikan umpan balik terhadap proses dan hasil pembelajaran;

merencanakan kegiatan tindak lanjut dalam bentuk pembelajaran remedi, program pengayaan, layanan konseling dan/atau memberikan tugas baik tugas individual maupun kelompok sesuai dengan hasil belajar peserta didik;

\section{Sumber Belajar}

a. Buku IPA Terpadu 
Joko Budi Poernomo

b. Buku kerja

c. Termometer

\section{Penilaian Hasil Belajar}

\begin{tabular}{|c|c|c|c|}
\hline $\begin{array}{l}\text { Indikator Penca- } \\
\text { paian }\end{array}$ & $\begin{array}{c}\text { Teknik } \\
\text { Penilaian }\end{array}$ & $\begin{array}{l}\text { Bentuk } \\
\text { Instrumen }\end{array}$ & Instrumen/ Soal \\
\hline $\begin{array}{l}\text { Menggunakan } \\
\text { termometer un- } \\
\text { tuk mengukur } \\
\text { suhu zat. }\end{array}$ & Tes tertulis & Tes uraian & $\begin{array}{l}\text { Mengapa tangan } \\
\text { manusia tidak } \\
\text { dapat dijadikan } \\
\text { alat ukur suhu, pa- } \\
\text { dahal tangan dapat } \\
\text { membedakan pa- } \\
\text { nas dan dingin? }\end{array}$ \\
\hline $\begin{array}{l}\text { Membandingkan } \\
\text { skala termometer } \\
\text { Celsius dengan } \\
\text { termometer yang } \\
\text { lain. }\end{array}$ & & & $\begin{array}{l}\text { Bila termometer } \\
\text { Celsius menunjuk- } \\
\text { kan skala } 80^{\circ} \text {, maka } \\
\text { skala Reamur akan } \\
\text { menunjukkan... } \\
\text { a. } 64^{0} \text { c. } 100^{\circ} \\
\text { b. } .96^{0} \text { d. } .150^{\circ}\end{array}$ \\
\hline
\end{tabular}

Mengetahui,

Kepala SMP/MTs
20 .........

Guru Mapel Ilmu Pengetahuan

Alam

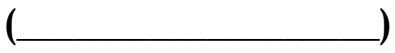

NIP/NIK :

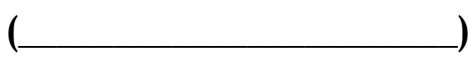

NIP/NIK :

162 Jurnal PHENOMENON, Volume 1 Nomor 1, Juli 2011 


\section{Mengembangkan Pembelajaran Pembentukan Karak- ter Indonesia}

\section{Kerangka Berpikir Pengembangan Pembentukan Karakter}

Tujuan ideal tersebut akan dapat dicapai lewat seluruh upaya pembangunan pendidikan, baik sektoral (pendidikan dg berbagai jenis dan jalur) dan lintas-trans sektoral (bersama bidang-bidang terkait lainnya) dengan strategi mikro (sekolah), meso (kebijakan dan manajemen sektoral), dan makro (kebijakan dan menajemen lintas sektoral) dari daerah sampai nasional. Meskipun hasil pendidikan dalam arti luas ditentukan secara bersama oleh apa yang terjadi/dilakukan di tripusat pendidikan dengan penerapan tiga tingkat strategi, fokus pembicaraan dalam pertemuan ini adalah strategi mikro (tingkat sekolah), khususnya wilayah pembelajaran, baik pada tingkat program maupun praktik kelas.

Dalam rangka memberi dasar bagi pengembangan pembelajaran pembentukan karakter Indonesia (P2KI) di sekolah hendaknya digunakan strategi mikro berbasis evaluasi dengan menerapkan kriteria legal, kontekstual dan substansial. Secara legal, diterapkan kriteria aturan yg berlaku, secara kontekstual diterapkan kriteria tuntutan perkembangan masyarakat, dan secara teknis substansial diterapkan konsep-konsep pendidikan yg mutakhir. Aturan yang berlaku utamanya Standar Isi, Standar Kompetensi Lulusan, Standar Proses dan Standar Penilain, dan Permendiknas lain yang relevan. Tuntutan perkembangan masyarakat berkenaan misalnya dengan demokratisasi, kewirausahaan (ekonomi kreatif), jatidiri, dan globalisasi. Konsep-konsep mutakhir pendidikan oleh Pemerintah telah diterjemahkan dalam konsep PAIKEM dengan pendekatan kontekstualnya. 
Selanjutnya rajutan kriteria diperluas untuk dikaitkan dengan Visi Pendidikan tingkat sekolah yang diilhami oleh Visi pendidikan tingkat provinsi dan nasional, yang semuanya tentu dalam rangka pembangunan secara umum, mulai dari daerah sampai ke nasional. Kerangka berpikir yang demikian selaras dengan semboyan ‘Bhineka Tunggal Ika', yang mengakui keragaman upaya bersama strategi, metode dan teknik, yang semuanya bermuara pada tujuan yang sama, tujuan pendirian NKRI, khususnya tujuan ketiga.

\section{Penyetaraan Kompetensi Awal}

Pembentukan kepribadian Indonesia lengkap dengan kecerdasan otak di Sekolah sebenarnya telah dimulai dari pendidikan anak usia dini PAUD, baik yang informal, nonformal, maupun formal. Namun perlu dicatat bahwa variasi penguasaan kompetensi awal hendaknya didukung dengan data empiris. Dalam hal ini, begitu selesai proses PPDB, segera dilakukan pemetaan kemampuan awal PDB melalui semacam tes pra-program yang valid dan reliabel. Sebenarnya kerangka dasar tes semacam ini dapat dirancang di tingkat provinsi dan kemudian sekolah mengembangkannya sesuai dengan keahlian masing-masing program. Dari hasil tes pra-program tersebut dapat dilihat tingkat penguasaan kompetensi awal. Jika ternyata terdapat variasi yang diduga dapat menghambat proses pembelajaran, maka perlu dirancang program matrikulasinya sesuai dengan kebutuhan. Upaya ini diiringi dengan identifikasi gaya belajar dan tipe kepribadian siswa. Dengan demikian, program pembelajaran di sekolah memiliki batu loncatan yang kokoh berupa kesetaraan kompetensi awal, yang diperkaya dengan informasi tentang karakeristik siswa. Program pembelajaran tersebut selanjutnya dirancang dengan pendekatan sys- 
tem (siklus input-process-output-outcome) untuk bermuara pada pencapaian SKL sekolah.

\section{Kerangka Mencapai Peningkatan Mutu Pembelaja- ran Karakter di Sekolah}

Lulusan yang cerdas berkarakter merupakan idaman setiap sekolah. Pembentukan karakter jelas dipengaruhi oleh perkembangan jiwa dan pengalaman siswa dalam lingkungan kehidupannya. Maka strategi yang digunakan juga perlu mempertimbangkan kedua faktor tersebut, yang sebenarnya dapat bertemu dalam pengembangan KTSP dalam di bawah manajemen berbasis sekolah sebagai penerapan desentralisasi pendidikan.

KTSP perlu dikembangkan (dirancang, dilaksanakan, dinilai) agar makin selaras dengan kebutuhan belajar siswa menuju terbentuknya karakter Indonesia dan berkembangkan kecerdasan intelektualnya. Sebaiknya, pengembangan KTSP dilakukan melalui siklus berbasis penilaian. Penilaian KTSP dapat mengikuti kerangka pijakan penilaian yang berlaku.

Dalam mengembangkan KTSP, perlu diperhatikan kesesuaian KTSP dengan tahap perkembangan jiwa anak, misalnya sesuai dengan tahapan perkembangan Piaget (proses internal dalam dalam diri anak) dan $\mathrm{Vy}-$ gotsky (proses interaksi dengan lingkungan anak). Dua hal yang perlu dipertimbangkan adalah: (1) Bahwa makin muda usia anak, makin konkret bahan/pengalaman belajar yang diperlukan untuk mendukung pengembangan potensinya; dan (2) Bahwa anak memerlukan interaksi aktif dengan lingkungan bersama unsur-unsurnya untuk mendukung perkembangan potensi sosialnya. (Lihat Gambar 9 dan 9 untuk kerangka pengembangan dan 
rancangan KTSP).

\section{Ranah dan Pelaksanaan Program Pembelajaran}

Dalam merancang dan melaksanakan dan menilai program pembelajaran, perlu dicermati apakah telah dipertimbangkan bahwa masing-masing jenis kompetensi memerlukan proses pembelajaran yang berbeda. Pertimbangannya dapat diringkas sbb.: (1) Kompetensi akademik/teoretik banyak melibatkan proses kognitif (otak kiri); (2) Kompetensi afektif (soft skills) banyak melibatkan proses rasa/hati (otak kanan) dengan hirarki menerimamenanggapi-menghargai-menata-mencirikhasi; (3)Kompetensi keterampilan banyak melibatkan gerak motorik; dan (4) keterampilan interaktif melibatkan proses berinteraksi verbal. Hirarki pembelajaran masing-masing dapat diringkas sebagai berikut: Hirarki kompetensi akademik mencakup pengetahuan-pemhaman-penerapananalisis-evaluasi-penciptaan (taknosomi Bloom, revisi th. 1997).

\section{a. Pembelajaran Kognitif}

Pembelajaran kognitif berkenaan dengan olah otak (belahan otak kiri), yaitu proses penguasaan pengetahuan (penyerapan informasi ke dalam ingatan jangka panjang). Pengetahuan dapat diklasifikasi menjadi: (a) pengetahuan faktual; (b) pengetahuan konseptual, dan (c) pengetahuan prosedural. Pengetahuan faktual adalah pengetahuan tentang hal-hal yang ciri-cirinya sudah tetap, misalnya luas Indonesia, ibukota negara/provinsi, nama provinsi dsb. Untuk pengetahuan faktual, proses menyerap dan menyimpannya dalam ingatan jangka panjang melibatkan pengulangan yang memadai. Jenis pengetahuan ini tidak perlu ditangani lewat pengajaran tatap muka, melainkan lewat penugasan perpustakaan di mana siswa diberi berbagai macam pertanyaan/tugas untuk mencari sendiri pengetahuan tersebut dan kemudian menyerahkan rangkuman tertulis dan/atau 
menyajikan rangkumannya di depan kelas. Jadi proses pembelajarannya termasuk kategori transmisi.

Sementara itu, pengetahuan konseptual dipelajari oleh siswa melalui proses transaksi atau negosiasi, di mana terjadi dialog dan/atau diskusi dengan guru dan di antara siswa dalam proses memahami konsep-konsep sasaran. Penggunaan media yang tepat sangat disarankan. Di sinilah taksonomi kognitif yang telah disebut di atas harus benarbenar diterapkan. Artinya, guru wajib membantu menciptakan tugas-tugas yang mendorong siswa untuk memantapkan pemahamannya, menerapkan konsep dalam berbagai situasi, menganalisis konsep dalam situasi penerapannya, mengevaluasi dan menciptakan hal baru dengan konsep tersebut. Menurut pengamatan penulis, kebanyakan guru masih terlalu menekankan proses menghafal untuk pengetahuan konseptual.

Pengetahuan prosedural adalah informasi tentang langkah-langkah untuk melakukan suatu pekerjaan. Terkandung dalam pengetahuan tersebut suatu rentetan tindakan sebagai kesatuan. Sebaiknya, untuk pengetahuan jenis ini, penekanan diberikan pada praktik yang taat prosedur. Akan tetapi siswa perlu disadarkan tentang pentingnya menaati setiap langkah: apa dampak positif jika taat, dan apa dampak negatif jika melanggar. Dengan demikian, siswa akan taat prosedur dengan pemahaman dan kesadaran penuh sehingga sikap akhirnya menjadi bagian dari karakternya.

\section{b. Pembelajaran Afektif}

Pembelajaran afektif berkenaan dengan olah hati (atau belahan otak kanan), termasuk aspek moral-spiritual, seni, rasa kebangsaan, dan sikap hidup. Tahapan pembelajaran afektif mencakup: (1) kesediaan siswa untuk memberi perhatian (penerimaan); (2) partisipasi aktif siswa (tanggapan); (3) pemberian makna pada objek, gejala, atau perilaku tertentu (penghargaan): (4) pengintegrasian berbagai nilai, menyelaraskannya untuk memulai sistem nilai yang baru (penataan); 
dan akhirnya (5) memulai 'gaya hidup' baru tertentu sesuai dengan nilai-nilai baru yang dipelajari. Jadi, pembelajran afektif tidak cukup hanya diberi ceramah, melainkan harus melalui kegiatan di mana siswa berlatih menentukan pilihan-pilihan dengan sadar, baik melalui simulasi pemecahan masalah atau pengalaman nyata, dan di dalamnya terjadi proses memberi umpan balik berupa saran perbaikan dan apresiasi, baik oleh sesama siswa maupun oleh guru, dan kesempatan untuk mempertahankan pendapat, keputusan, dan/atau pendirian. Siswa perlu diberi kesempatan untuk menentukan pilihan secara pribadi dan secara kelompok, dan semuanya diberi bobot nilai yang sesuai. Hanya dengan proses yang benar-benar melibatkan siswa untuk menimbang-nimbang anatar yang baik-buruk, yang bermanfaatmudhorot, dan yang boros-hemat, pebmentukan karakter yang kokoh akan terlaksana.

\section{c. Pembelajaran Keterampilan Psikomotor}

Pada hakikatnya, setiap Peserta didik memerlukan keterampilan, paling tidak untuk memenuhi kebutuhan pribadinya dalam kehidupan sehari-hari sehingga dapat berkembang menjadi insan mandiri. Semua ini perlu dilatihkan secara terprogram.

Untuk membuat kegiatan menjadi menarik, ada dua jenis kegiatan: (1) kegiatan wajib, dan (2) begiatan pilihan. Kegiatan wajib mencakup semua kegiatan yang melatih siswa untuk melakukan semua hal yang dibutuhkan sehari-hari oleh siswa. Misalnya, mereka perlu belajar mencuci pakaiannya sendiri, menyetrika pakaian, memasang kancing, memperbaiki jahitan, membuat meniman, memasak makanan pokok yang dibutuhkan, membuat atau memperbaiki sesuatu yang diperlukannya dalam kehidupan rumah tangga seperti menggergaji, mamasang paku, memotong dengan pisau, dan menggunakan cangkul dan cetok. Tentu semua ini disesuaikan dengan lingkungan hidup siswa. Kegiatan pilihan adalah kegiatan membuat pra-karya (kerajinan) dengan 
bahan-bahan yang ada di lingkungan hidup siswa, baik yang baru maupun bekas (daur ulang). Kegiatan latihan berkarya dapat dikemas sedemikian rupa sehingga siswa berkesempatan membuat rencana kerja dengan rincian kebutuhan akan tenaga manusia, dana, dan waktu untuk menyelesaikan tugas membuat sejumlah prak-karya dalam waktu yang ditentukan. Dengan demikian, mereka telah dikenalkan dengan kewirausahaan.

Yang perlu diperhatikan adalah bahwa untuk mencapai pra-karya dan karya yang berkualitas, perlu diperhatikan tahapan pembelajaran keterampilan, yang meliputi: (1) Pemerolehan pengetahuan (tentang apa yang mesti dilakukan, untuk tujuan apa, dengan urutan bagaimana); (2) Melaksanakan langkah demi langkah latihan yang diberikan; (3) Pengalihan kendali dari mata ke rasa; (4) Otomatisasi keterampilan (lewat latihan intensif); dan akhirnya (5) Generalisasi penggunaan keterampilan dalam penerapan dalam berbagai situasi. Untuk semua tahapan ini Peserta Didik hendaknya disadarkan pentingnya melakukannya dengan sungguh. Selain itu, mereka mesti diberitahu kriteria yang diterapkan dalam penilaian kinerja mereka.

\section{d. Keterampilan Interaktif}

Dalam kehidupan nyata, anak-anak perlu bergaul dan beruruan dengan orang lain, yang kebanyakan dilakukan dengan medium bahasa. Oleh sebab itu, mereka perlu dilatih untuk melakukan interaksi verbal. Proses berinteraksi yang perlu dilatihkan pada siswa mencakup perilaku: mengusulkan, mengembangkan (usulan atau gagasan sebelumnya), mendukung (usulan atau gagasan orang lain); tidak setuju pada gagasan orang lain; mempertahankan/menyerang gagasan orang lain; menghalangi/menyangkal/menghambat orang lain; terbuka (mengakui kesalahan sendiri atau kehebatan orang lain; menguji pemahaman; merangkum; mencari informasi; memberi informasi; menghentikan bicara orang lain; melibatkan orang lain (Rackham \& Morgan 
dalam Romiszowski, 1981).

\section{e. Tahapan Pembentukan Karakter}

Pembentukan karakter merupakan proses sepanjang siswa menempuh pendidikan. Untuk itu, perlu ditentukan langkah-langkah strategis untuk membantu siswa mengembangkan karakternya dengan bekal potensi/kemampuan yang telha dianugerahkan oleh Tuhan YME. Tahap paling awal dari proses pembentukan karakter adalah membantu siswa mengenal dan menerima dirinya sendiri. Hal ini dapat dilakukan dengan melibatkan mereka dalam berbagai kegiatan terpantau, baik akadmeik mapun non-akademik. Kinerja siswa diamatai dan kepada mereka diberikan umpan balik, baik secara tertulis maupun lisan. Dari umpan balik itulah, siswa dibimbing untuk memahami kelebihan dan kekurangan dirinya, dan akhirnya menerima dirinya sendiri.

Tahap berikutnya adalah membimbinga siswa untuk menentukan pilihan-pilihan kegiatan sesuai dengan tingkat kemampuan, bakat dan minat masing-masing. Setelah pilihannya dilaksanakan, kinerjanya yang bagus diberikan apresiasi, tetapi untuk kinerja yang kurang bagus diberikan dorongan untuk bekerja lebih keras lagi dan diyakinkan bahwa siswa akan bisa menyelesaikan asalkan mau berusaha dengan waktu memadai. Atau jika siswa ternyata salah memilih, mereka diberi kesempatan lagi untuk menentukan pilihan lain dan kemudian melaksanakannya, dengan diiringi dengan umpan balik yang memberi semangat. Untuk ini, guru perlu menciptakan tugas-tugas dengan jenis dan tingkat kesulitan yang berbeda. Strategi berbasis perkembangan jiwa dalam menanamkan nilai-nilai yang diinginkan dapat diringkas sebagai berikut: (1) makin muda usia anak, tekanan diberikan pada (a) pembiasaan perilaku diselingi dengan diskusi dengan siswa dan (b) penjelajahan lingkungan terdekat dan membahas hasil yang dipaparkan siswa; dan (2) makin tua usia siswa, tekanan diberikan (a) penya- 
daran dan pemahaman nilai lewat analisis kritis terhadap perilaku sadar dalam situasi kehidupan dan (b) penjelajahan lingkungan yang makin jauh dab diskusi persoalan-persoalan di dalamnya.

\section{f. Melibatkan Siswa dalam Pengalaman Berkearifan Lo- kal dan Nasional}

Untuk memperkokoh dasar-dasar karakter, siswa dapat dilibatkan dalam berbagai kegiatan yang mengandung kearifan lokal, termasuk: (1) praktik budaya lokal dan nasional; (2) Menjelajah lingkungan dan mengidentifikasi potensi sumber daya (alam, sosbud) dan membuat laporan yang dipaparkan dan dianalisis bersama; (3) sarasehan untuk menganalitis kekayaan (alam, sosbud) Indonesia secara umum; (4) Berkarya/ berprakarya (perorangan \& kelompok) dengan memanfaatkan sumberdaya \&limbah yang ada; (5) Kerja bakti membersihkan dan memperindah lingkungan sekolah; (6) Kemah di alam terbuka diiringi kegiatan-kegiatan yang merangsang tumbuhnya kemandirian dan keberanian mengambil resiko; (7) Praktik budaya lokal (pakaian, kuliner, seni, OR); (8) Membaca ceritera rakyat pilihan, novel pilihan; (9) Cerdas cermat tentang kekayaan lingkungan alam dan sosbud serta sejarah di lingkup lokal dan nasional/internasional; (10) Wisata belajar (terarah)-lokal, provinsi lain; (11) Belajar lagu-lagu daerah, lagu-lagu nasional, lagulagu perjuangan; (12) Membaca biografi tokoh-tokoh lokal dan nasional.

Praktik budaya lokal dan nasional dapat dilakukan dengan melibatkan siswa dalam: (1) Menggunakan bahasa daerah untuk tujuan komunikasi, baik dalam hari-hari tertentu dan/atau dalam acara-acara budaya tertentu seperti syawalan; (2) Memakai pakaian daerah; (3) Mengenakan pakaian bahan dan motif lokal (batik dan lurik); (4) Memainkan alat musik daerah' (5) Membuat kerajinan (keramik, batik dll); (6) Menyantap makanan daerah, yang telah dimodi- 
fikasi sehingga memenuhi kandungan gizi; (7) Membuat/ memasak makanan daerah dengan modifikasi bumbu dan bahan sehingga sehat; (8) Menyanyikan lagu-lagu daerah; dan (9) Praktik permainan/seni tradisional; serta (10) praktik melakukan upacara tradisional.

Dalam berprakarya hal-hal berikut ditekankan: (1) Pemanfaatkan bahan/limbah yg ada di lingkungan anak; (2) Menggunakan acuan Iptek (konsep-konsep biologi, kimia, fisika, matematika) \& prosedur/manual); (3) Perencanaan setiap prakarya (pencarian bahan, perkiraan waktu/ tenaga/biaya/harga penjualan); dan (4) Evaluasi pelaksanaan prakarya sebelumnya untuk perbaikan selanjutnya. Sebagai contoh, anak diminta untuk: (1) membuat prakarya dari kertas karton, sekaligus mencatat kebutuhan waktu \& bahan; (2) menghitung waktu, bahan, dan tenaga jika harus membuat 100 biji; (3) merencanakan pembuatan 100 biji tsb dalam 5 jam shg dapat menentukan brp orang yg diperlukan utk mengerjakannya; (4) menghitung harga jual satu biji utk meraih keuntungan 10\%; (5) membuat manual prosedur/langkah pembuatan; dan (6) mencari acuan iptek tentang sifat karton untuk dasar pembuatan 'peringatan bagi pengguna barang' ttg hal-hal yang perlu dilakukan atau dihindari untuk memeliharanya.

Untuk menjamin pelaksanaan pendidikan karakter, perlu dikembangkan: (1) Indikator-indikator keberhasilan pendidikan karakter, yang peka budaya lokal sehingga tidak bisa seragam secara nasional; (2) Pedoman dan instrumen penilaiannya; (3) Teknik penyajian hasil penilaian terhadap perkembangan karakter peserta didik; dan (4) Bobot nilai karakter dalam evaluasi belajar peserta didik.

Tidak kalah pentingnya, pendidikan karakter hendaknya diiringi dengan penelitian untuk mendukung pengembangannya secara konsisten sehingga benar-benar mendukung tercapainya fungsi dan tujuan pendidikan nasional. Dalam melakukan penelitian hendaknya dijalin kerjasama dan kolaborasi dengan perguruan tinggi yang relevan. 


\section{E. Penutup}

Dari uraian di atas, dapat dibuat simpulan-simpulan berikut: (1) Pembentukan karakter telah diamanatkan oleh UU Sisdiknas; (2) Karakter memiliki dimensi kecerdasan pikiran, kepekaan hati nurani, kepedulian diri dan lingkungan, kecergasan bertindak, dan kesehatan, kebugaran, kekuatan jasmani; (3) Pembentukan karakter hendaknya menjadi kepedulian bersama bagi seluruh komunitas sekolah bersdama pemangku kepentingan terkait; (4) Pembelajaran berorientasi pada pembentukan karakter perlu menerapkan kriteria legal, konseptual, dan kontekstual dalam penialian programnya; (5) Pembelajaran pembentukan karakter akan berhasil jika dikelalola dengan baik dengan menerapkan prinsip-prinsip MBS; (6) Pembelajaran pembentukan karakter perlu didukung dengan penelitian tindakan, penelitan terapan/pengembangan, dan penelitian evaluatif dengan bekerjasama dengan perguruan tinggi, (7) pada tingkatan awal perlu adanya kesamaan visi dalam mengembangkan perangkat pembelajaran, penilaian yang berorientasi pada pemunculan nilai-nilai karakter yang mengedepankan siswa yang cerdas, beretika dan memiliki kepedulian terhadap lingkungan mereka berada. 


\section{DAFTAR PUSTAKA}

Arikunto, Suharsimi. 2006. Kurikulum KTSP SMP. Standar Isi Mata Pelajaran SMP. Jakarta : Depdiknas.

Arikunto, Suharsimi. 2006. Kurikulum KTSP SMP. Pedomam Khusus Pengembangan Silabus. Jakarta : Depdiknas.

Dick, W \& Carey, L. 2001. The systematic Design of Instruction. 5th edition. New York Longman.

Arikunto, Suharsimi. 1990. Dasar-Dasar Evaluasi Pendidikan. Jakarta : Bumi Aksara

Pusat kurikulum, Balitbang. 2010. Pengembangan Pendidikan Budaya dan Karakter Bangsa. Jakarta : Kemendiknas.

Sunarsih M, Pembentukan karakter Mandiri system Desentralistik, makalah, Universitas Negeri Yogyakarta.

Tim. 2010. Panduan Pembinaan Pendidikan Karakter Di SMP

Bilgin, Ibrahim (2009). The effects of guided inquiry instruction incorporating a cooperative learning approach on university student achievement of acid and base concepts and attitudetoward guided inquiru instruction, Scientific Research and Essay Vol.4 (10),

pp. 1038 - 1045, October, 2009

Wiyanto, 2008. Menyiapkan Guru Sains Mengembangkan Kompetensi Laboratorium. Semarang: Unness Press. 